\title{
DIAGNOSIS KESULITAN BELAJAR MATEMATIKA SISWA KELAS V DI MADRASAH IBTIDAIYAH MUNA WARIYAH PALEMBANG
}

\author{
Mardiah Astuti
}

Fakultas Ilmu Tarbiyah dan Keguruan UIN Raden Fatah Palembang diah_fajri@yahoo.co.id

\section{Tutut Handayani}

Fakultas Ilmu Tarbiyah dan Keguruan UIN Raden Fatah Palembang tututhandayani78@yahoo.co.id

\section{Nike Ardilah}

AlumniProdi PGMIFakultas Ilmu Tarbiyah dan Keguruan UIN Raden Fatah Palembang

\begin{abstract}
Abstrak
Tujuan penelitian ini ialah mengetahui kesulitan belajar siswa ketika belajar materi penggunaan sifat-sifat operasi hitung di Kelas VB Madrasah Ibtidaiyah Munawariyah Palembang, untuk mengetahui penyebab kesulitan siswa ketika belajar matematika di Kelas VB Madrasah Ibtidaiyah Munawariyah Palembang, dan untuk mengetahui upaya yang dilakukan guru matematika di Kelas VB Madrasah Ibtidaiyah Munawariyah Palembang.Metode penelitian yang dilakukan ialah deskriptif kualitatif. Adapun hasil penelitian, pertama, kesulitan yang dialami siswa pada pelajaran matematika materi penggunaan sifat-sifat operasi hitung di Kelas VB Madrasah Ibtidaiyah Munawariyah Palembang yaitu kelemahan pemahaman konsep, ketidakmampuan siswa dalam berhitung, ketidakmampuan siswa dalam memahami simbol matematika, dan ketidakmampuan siswa dalam memahami perkalian. Kedua, penyebab kesulitan belajar matematika meliputi: (1) Faktor internal adalah kemampuan intelektual siswa yang rendah, sikap belajar siswa cenderung malas sehingga dapat siswa kesulitan menyelesaikan soal(2) Faktor eksternal siswa adalah guru, lingkungan keluarga kurang mendukung, dan lingkungan sekolah yang berisik.
\end{abstract}

Kata-kata kunci: diagnosis, kesulitan, belajar.

Abstract

This research aims to find out the difficulties of students in learning subject of arithmetic operations in class VB of Ibtidaiyah Munawariyah Palembang, to see the factors that caused the difficulties of students when studying mathematics in the VB class of Palembang Ibtidaiyah Munawariyah, and also for knowing the efforts made by the mathematics teacher in overcoming the difficulties of students in the VB class of Palembang Madrasah Ibtidaiyah Munawariyah. This research is guided by qualitative descriptive methods. The results shows that, first, the difficulties of students in learning subject of arithmetic operations in class VB of Ibtidaiyah Munawariyah Palembang are inability of students in mastering mathematic concepts correctly, inability of students to count, inability of students to understand mathematical symbols, and inability students in understanding

JP: Jurnal Ilmiah PGMI, Volume 5 No. 1, Juni 2019

Available Online at http:/jurnal.radenfatah.ac.id/index.php/jip/ 
multiplication. Second, the factors that caused the difficulties of students when studying mathematics are: (1) internal factors that students have low intellectual ability and tend to be lazy in studying mathematics thus it can cause students to make mistakes in working on the problem. (2) external factors that caused the difficulties of students in learning subject of arithmetic operations are lack of support that given by teachers and family, and noisy school environment. Third, the efforts made by mathematics teachers in overcoming the difficulties of students in learning subject of arithmetic operations are the need of special teaching such as tutoring, using innovative and creative media or teaching methods to facilitate students, and creating conditioning (reinforcement, rewards, encouragement), and drill.

Keywords : Diagnosis, difficulties, learning

\section{PENDAHULUAN}

Sudah diketahui bahwa pendidikan adalah sektor yang sangat menentukan kualitas suatu bangsa. Faktor utama dalam pendidikan adalah guru.Di dalam dunia pendidikan, istilah guru bukanlah hal yang asing.Guru bertanggungjawab dalam mencerdaskan anak didiknya, Guru Berdedikasi untuk membimbing dan membina siswa agar kelak berguna bagi nusa dan bangsa (Hawi, 2006: 15). Oleh karena itu, guru memegang peranan penting dan strategis sebagai mengajar, mendidik, mengasuh, membimbing dan mengevaluasi para siswa, sebab itulah guru merupakan agen perubahan sosial yang dapat merubah pola pikir, sikap dan perilaku seseorang menuju kehidupan yang lebih baik.

Pendidikan tidak terlepas dari proses pembelajaran, baik dalam pendidikan formal, informal dan nonformal yang mana proses tersebut terlaksana karena adanya interaksi antara pendidik dan peserta didik. Di dalam pelaksanaan proses pembelajaran di sekolah, khususnya anak-anak diusia sekolah dasar atau madrasah ibtidaiyah (SD/MI) sering mengalami kesulitan dalam menerima pelajaran dari guru. Kesulitan yang mereka hadapi ini merupakan problema yang sering menjadikan mereka kesulitan dalam memahami, dan mengaplikasikan atau dalam upaya meningkatkan kemampuan mereka terhadap mata pelajaran yang dipandang menakutkan.

Khususnya mata pelajaran matematika, sering sekali mereka mengalami kesulitan baik dalam memahami, maupun mengaplikasikannya dalam kehidupan 6

JP: Jurnal Ilmiah PGMI, Volume 5 No. 1, Juni 2019 Available Online at http:/jurnal.radenfatah.ac.id/index.php/jip/ 
sehari-hari. Hal ini sering terlihat anak-anak cenderung bersifat pasif dan mendapatkan nilai rendah di sekolah. Selain itu kesulitan dari memahami materi matematika apabila mendapat tugas oleh gurunya tidak dapat melaksanakannya dengan baik dan hal ini menyebabkan prestasi belajarnya menurun. Apalagi, tujuan dari pembelajaran matematika ini akan mencapai hasil yang maksimal apabila pembelajaran berjalan secara efektif. (Zubaidah Amir dan Risnawati,2016 : hlm. 8).

Aktivitas belajar siswa bersifat individual tidak selamanya berlangsung secara sempurna. Ada siswa yang ketika dalam pelaksanaan pembelajarannya tidak mengalami kesulitan, namun ada juga siswa yang dalam proses pembelajarannya tidak dapat berlangsung dengan baik karena adanya beberapa faktor yang mempengaruhinya.

Berdasarkan observasi awal yang dilaksanakan pada tanggal 30 Mei 2017 di kelas V B Madrasah Ibtidaiyah Munawariyah Palembang, peneliti menemukan gejala-gejala seperti masih banyaknya siswa yang belum bisa penjumlahan, pengurangan, perkalian dan pembagian dan siswa cenderung bersifat pasif serta hasil belajar siswa 75\% yang belum mencapai KKM (Observasi Awal, 30 Mei 2017).

Gejala-gejala seperti yang dikemukakan di atas disebabkan oleh beberapa kemungkinan seperti kurangnya pendekatan dan pembinaan oleh guru secara individual terhadap siswa-siswa yang mengalami kesulitan belajar matematika. Kurangnya perhatian dan pembinaan dari orang tua. Semestinya hal ini dapat diperbaiki apabila antara guru, wali kelas dan orang tua siswa saling bekerja sama dalam mengatasi hal tersebut. Dari pihak guru dapat memberikan solusi dengan mengulangi kembali penjelasan materi yang belum dimengerti oleh siswa. Kemudian, guru dapat melakukan pendekatan secara langsung kepada siswa yang dianggap memiliki permasalahan dalam menerima pelajaran matematika. Sedangkan permasalahan kurangnya perhatian dan pembinaan orang tua dapat diatasi dengan cara agar lebih memperhatikan segala aktifitas anaknya dan berkomunikasi baik-baik ketika akan berbicara dengan anak. 
Berdasarkan latar belakang di atas, peneliti tertarik untuk melakukan penelitian tentang diagnosis kesulitan belajar Matematika pada materi penggunaan sifat-sifat operasi hitung di kelas V B Madrasah Ibtidaiyah Munawariyah Palembang.

Adapun rumusan masalah dalam penelitian ini adalah sebagai berikut: (1) Apa saja kesulitan belajar siswa ketika belajar materi penggunaan sifat-sifat operasi hitung di Kelas VB MI Munawariyah Palembang?, (2) Apa saja faktorfaktor yang menyebabkan kesulitan belajar yang dialami siswa ketika belajar matematika di Kelas VB MI Munawariyah Palembang?, dan (3) Apa upaya yang dilakukan guru matematika dalam mengatasi kesulitan belajar siswa di Kelas VB MI Munawariyah Palembang?

\section{METODE PENELITIAN}

Penelitian ini merupakan penelitian kualitatif, dengan pendekatan diagnosis. Lokasi penelitian adalah di MI Munawariah Palembang. Subjek penelitian adalah kelas VB. Teknik sampling menggunakan nonprobably sampling. Analisis data menggunakan data reduksi, data simply, dan penyimpulan.

\section{HASIL DAN PEMBAHASAN}

\section{Kesulitan Belajar Matematika pada Materi Penggunaan Sifat-Sifat Operasi Hitung Madrasah Ibtidaiyah Munawariyah Palembang}

Sudah kita ketahui bahwa matematika merupakan bidang studi yang dipelajari oleh semua siswa dari SD hingga SLTA dan bahkan juga di perguruan tinggi. SD/MI merupakan pendidikan dasar bagi anak. Artinya, pemahaman matematika siswa ketika SD/MI berpengaruh besar hingga jenjang selanjutnya.

Dalam pembelajaran matematika, siswa mengembangkan suatu konsep ketika mereka mampu mengklasifikasikan atau mengelompokkan benda-benda atau ketika dapat mengasosiasikan suatu nama dengan kelompok benda tertentu. Sebagai contoh anak mengenal konsep segitiga sebagai suatu bidang yang dikelilingi oleh tiga garis lurus. Pemahaman anak tentang konsep segitiga dapat 8

JIP: Jurnal Ilmiah PGMI, Volume 5 No. 1, Juni 2019 Available Online at http:/jurnal.radenfatah.ac.id/index.php/jip/ 
dilihat pada saat anak mampu membedakan berbagai bentuk geometri lain. Jika konsep menunjuk pada pemahaman dasar, artinya keterampilan menunjuk pada sesuatu yang dilakukan oleh seseorang. sebagai contoh, proses menggunakan operasi dasar dalam penjumlahan, pengurangan, perkalian, dan pembagian adalah suatu jenis keterampilan matematika.

Dalam pembelajaran matematika, pemecahan masalah merupakan bagian yang paling sulit dalam pelajaran matematika. Sebagaimana dari data lapangan banyak siswa yang mengalami kesulitan belajar matematika apalagi pada materi penggunaan sifat-sifat operasi hitung. Seperti dalam pemahaman materi penggunaan sifat-sifat operasi hitung di Madrasah Ibtidaiyah Munawariyah Palembang peneliti melakukan wawancara dan observasi. Pada materi tersebut siswa sering mengalami kesulitan dalam mempelajari sifat komunikatif, sifat asosiatif, dan sifat distributif seperti ada yang ditukar ditambah, dikelompokkan dikali ditambah, dan dibalikkan dikali ditambah. Oleh karena itu, siswa kebingungan dalam menyelesaikan masalah tersebut.

Berdasarkan hasil wawancara kepada Ibu A selaku guru matematika Madrasah Ibtidaiyah Munawariyah Palembang menyebutkan bahwa:

Menurut saya kegiatan di sekolah yang diikuti oleh siswa, tidak semua bisa diikuti dan tidak semua siswa sukai bahkan ada yang memang berkesulitan dalam belajar tersebut, baik itu mata pelajaran atau kegiatan-kegiatan lainnya. Kemudian berbicara masalah kesulitan belajar matematika pada materi penggunaan sifat-sifat operasi hitung yang dialami oleh siswa kelas VB Madrasah Ibtidaiyah Munawariyah Palembang mereka menganggap bahwa materi yang diajarkan itu sulit dan susah dipahami oleh mereka. Contohnya: pada saat saya menjelaskan materi tentang penggunaan sifatsifat operasi hitung saya sering melihat ada (1) ketidakmampuan siswa dalam penguasaan konsep secara benar, seperti konsep penjumlahan dan perkalian itu siswa kelihatan bingung sehingga dapat menyebabkan ketidakmampuan siswa dalam penguasaan konsep itu kurang, (2) ketidakmampuan siswa dalam berhitung, seperti penjumlahan, sehingga pada saat menjawab tugas yang diberikan guru ada siswa yang keliru dalam menjawab, (3) ketidakmampuan siswa dalam memahami tentang simbol matematika, dan (4) ketidakmampuan siswa dalam memahami perkalian (Wawancara, Tanggal 06 September 2017. Pukul 09.18). 
Adapun hasil wawancara peneliti kepada siswi-siswa kelas VB tentang jenis apa saja yang menurut mereka kesulitan belajar matematika pada materi penggunaan sifat-sifat operasi hitung.

Sebagimana yang dikemukakan MH tentang kesulitan belajar matematika pada materi penggunaan sifat-sifat operasi hitung yang dialami, ia mengungkapkan bahwa:

Menurut saya mata pelajaran matematika itu sangat sulit untuk dipahami dan dimengerti, karena terlalu banyak pembagian-pembagian. Seperti materi penggunaan sifat-sifat operasi hitung saya tidak terlalu suka di assosiatif sampai-sampai ketika pembelajaran berlangsung saya ribut. Dan juga saya sering mendapatkan nilai yang rendah yaitu berkisar 30 sampai 50. Apalagi pada saat guru menyampaikan materi terlalu cepat. Sehingga ketika guru memberikan tugas saya terkadang menyontek punya teman (Wawancara, MH, Tanggal 06 September 2017. Pukul 08.08).

Kemudian yang dikemukakan SZ tentang kesulitan belajar matematika pada materi penggunaan sifat-sifat operasi hitung yang dialami, ia mengungkapkan bahwa:

Pelajaran matematika adalah pelajaran yang susah dan saya tidak senang ketika belajar matematika. Dan gurunya dalam menyampaikan materi juga terlalu cepat dan tidak berulang-ulang. Sampai-sampai pada saat pembelajaran berlangsung saya tidak memperhatikan melainkan asyik bercerita tentang hantu dengan teman sebangku dan sering menyontek punya teman ketika diberikan tugas oleh guru. Apalagi pada materi penggunaan sifat-sifat operasi hitung saya tidak suka dan menurut saya itu terlalu susah karena ada penjumlahan. Apalagi nilai yang sering dapatkan juga rendah yaitu 40 sampai 70 (Wawancara, SZ, Tanggal 06 September 2017. Pukul 10.12).

Selanjutnya yang dikemukakan AF tentang kesulitan belajar matematika pada materi penggunaan sifat-sifat operasi hitung yang dialami, ia mengungkapkan bahwa:

Bagi saya matematika itu pelajaran yang susah karena adanya perkalian dan nilai yang saya dapatkan juga kecil yaitu 20 sampai 66. Apalagi guru dalam menyampaikan materi terlalu cepat yang membuat saya lambat dalam memahami dan mengerti. Sehingga pada saat pembelajaran berlangsung saya kadang bercerita dan kadang ribut. Apalagi materi yang pelajari adalah materi penggunaan sifat-sifat operasi hitung itu saya tidak suka dan susahnya di assosiatif (pengelompokkan) karena harus dikelompokkan dan 
dikalikan sehingga hasilnya sama (Wawancara, AF, Tanggal 06 September 2017. Pukul 07.17).

Sebagaimana yang dikemukakan AA tentang kesulitan matematika belajar pada materi penggunaan sifat-sifat operasi hitung yang dialami, ia mengungkapkan bahwa:

Menurut saya pelajaran matematika itu sangat mudah dan nilai yang didapatkan cukup besar yaitu 70, 75 dan 80. Apalagi materi penggunaan sifat-sifat operasi hitung saya senang karena di materi ini ada yang ditukarkan (komutatif), dikelompokkan (asosiatif), dan dibalikkan (distributif). Sehingga pada saat guru menyampaikan saya duduk diam dan memperhatikan penjelasan dari guru. Akan tetapi, saya tidak suka belajar bahasa Indonesia karena bahasa Indonesia itu saya sulit dalam membuat cerita. Apalagi nilai saya kecil yaitu 50 (Wawancara, A, Tanggal 06 September 2017. Pukul 10.30).

Selain itu, juga dikemukakan MFR tentang kesulitan belajar matematika belajar pada materi penggunaan sifat-sifat operasi hitung yang dialami, ia mengungkapkan bahwa:

Karena pelajaran matematika itu sangat mudah. Seperti materi penggunaan sifat-sifat operasi hitung itu saya senang karena ada penjumlahan dan perkalian. Sehingga nilai yang saya didapatkan yaitu 67 sampai 100 . Menurut saya pelajaran IPA itu sangat susah di dalam pilihan ganda. Sehingga saya. Kemudian pada saat guru menyampaikan materi saya mendengarkan dengan jelas penjelasan dari guru. Dan ketika diberikan tugas oleh guru saya kerjakan sendiri. Dan saya tidak menyukai pelajaran IPA, karena saya susah dalam soal pilihan ganda, terus nilai yang didapatkan kecil yaitu 20. Dan gurunya pun tidak kreatif sehingga siswa yang ribut tidak ditegur (Wawancara, M.FR, Tanggal 06 September 2017. Pukul 08.45).

Kemudian IKP juga mengemukakan tentang kesulitan belajar matematika belajar pada materi penggunaan sifat-sifat operasi hitung yang dialami, ia mengungkapkan bahwa:

Menurut saya materi penggunaan sifat-sifat operasi hitung itu terlalu sukar. Sehingga pada saat diberikan tugas oleh guru saya terkadang menyontek punya teman. Dan nilainya pun sangat kecil yaitu 45 sampai 70. Makanya sampai sekarang saya tidak begitu senang dengan matematika. Apalagi gurunya telalu cepat menyampaikan materi. Dan saya merasa mata pelajaran SKI mudah dan nilainya pun besar yaitu 60, 80, 90 dan 100 (Wawancara, IKP, Tanggal 06 September 2017. Pukul 09.30). 
Berdasarkan hasil wawancara yang dilakukan peneliti kepada guru dan siswa-siswi kelas VB mengenai kesulitan belajar matematika pada materi penggunaan sifat-sifat operasi hitung yaitu bahwa pada saat guru menyampaikan materi guru tersebut melihat ketidakmampuan siswa dalam penguasaan konsep penjumlahan dan perkalian, ketidakmampuan siswa dalam berhitung, dan ketidakmampuan memahami perkalian. Oleh karena itu, dari 6 orang siswa terdapat 4 orang yang tidak menyukai pelajaran matematika dilihat dari nilai yang tidak sesuai dengan KKM, 2 orang yang menyukai pelajaran matematika dilihat dari nilai yang sesuai dengan KKM. Sehingga 4 orang tersebut mengalami kesulitan belajar matematika terutama pada materi penggunaan sifat-sifat operasi hitung. Bahkan pada materi tersebut siswa sering merasa susah dan bingung, karena ada yang ditambah, dikali, ditukar, dikelompokkan, dan dibalikkan. Sampai-sampai ketika guru memberikan siswa tersebut menyontek punya temannya.

Berdasarkan hasil analisis dokumen kesulitan belajar matematika pada materi penggunaan sifat-sifat operasi hitung, peneliti melihat perhatian atau minat siswa ketika belajar penggunaan sifat-sifat operasi hitung dari jumlah 37 orang siswa hanya 10 orang siswa yang berantusias ingin menjawab pertanyaan dari guru mengenai materi tersebut. Pada materi tersebut bahwa siswa mengalami kesulitan dalam belajar sifat asosiatif dan distributif. Peneliti melihat dari keseluruhan siswa terhadap dokumen latihan, nilai yang dimiliki atau yang didapat oleh siswa saat tugas yang diberikan oleh guru, menunjukkan bahwa ratarata yang didapatkan oleh siswa dibawah rata-rata atau KKM itu sendiri bahkan ada siswa yang mendapat nilai yang sangat kecil (Observasi, Tanggal 04 September 2017. Pukul 09.15).

Adapun berdasarkan data di atas dari hasil wawancara yang dilakukan oleh peneliti, observasi dan telaah dokumentasi terkait kesulitan belajar matematika pada materi penggunaan sifat-sifat operasi hitung, dapat disimpulkan bahwa pada saat guru menyampaikan materi guru tersebut melihat ketidakmampuan siswa dalam penguasaan konsep penjumlahan dan perkalian, dan ketidakmampuan 12 
siswa dalam berhitung. Oleh karena itu, dari 6 orang siswa terdapat 4 orang yang tidak menyukai pelajaran matematika dilihat dari nilai yang tidak sesuai dengan KKM, 2 orang yang menyukai pelajaran matematika dilihat dari nilai yang sesuai dengan KKM. Sehingga 4 orang tersebut mengalami kesulitan belajar matematika terutama pada materi penggunaan sifat-sifat operasi hitung. Bahkan pada materi tersebut siswa sering merasa susah dan bingung, karena ada yang ditambah, dikali, ditukar, dikelompokkan, dan dibalikkan. Sampai-sampai ketika guru memberikan tugas kepada siswa, siswa tersebut sering mencontek punya temannya. Namun, ketika dilihat dari dari beberapa hasil observasi yang dilakukan peneliti tidak melihat penggulangan terhadap materi yang diajarkan sehingga membuat siswa sulit untuk memahami dan mengerti.

\section{Faktor-faktor Penyebab Kesulitan Belajar Matematika pada Penggunaan Sifat- Sifat Operasi Hitung Madarasah Ibtidaiyah Munawariyah Palembang \\ Untuk mengetahui faktor penyebab kesulitan belajar matematika pada} materi penggunaan sifat-sifat operasi hitung di MI Munawariyah Palembang peneliti melakukan wawancara dan observasi.Berdasarkan hasil wawancara yang dilakukan peneliti kepada guru matematika mengenai faktor-faktor penyebab kesulitan belajar matematika pada materi penggunaan sifat-sifat operasi hitung, yaitu:

Ada beberapa faktor yang menyebabkan kesulitan belajar, yaitu:

\section{Faktor Internal}

Contoh: adanya siswa yang tidak disiplin dalam belajar, konsentrasi belajar tidak bertahan lama, dan kemampuan mengingat siswa rendah. Serta dalam mengerjakan soal, maksudnya kesulitan dalam memahami soal.

\section{Faktor Eksternal}

Contoh: Guru dalam memberikan pemahaman yang kurang jelas, lingkungan keluarga kurang mendukung, dan lingkungan sekolah yang berisik. (Wawancara, A, Tanggal 06 September 2017. Pukul 09.18)

Berdasarkan hasil analisis dokumen, pada materi penggunaan sifat-sifat operasi hitung peneliti melihat bahwa dalam belajar materi tersebut ada sebagian 
siswa yang merasa sulit dalam memahami soal, sehingga pada saat latihan sering mendapatkan nilai yang tidak sesuai dengan KKM atau nilai rendah dan menyontek punya temannya. Sampai-sampai minat siswa terhadap materi tersebut kurang dalam belajar.

Dari uraian di atas dapat disimpulkan bahwa faktor yang menyebabkan kesulitan belajar matematika pada materi penggunaan sifat-sifat operasi hitung, yaitu: faktor mengerjakan soal, faktor internal dan faktor eksternal. Faktor yang menyebabkan siswa melakukan kesalahan dalam mengerjakan soal adalah siswa kesulitan dalam memahami maksud soal; kurang memahami konsep sifat-sifat operasi hitung; konsep memahami dan menghafal rumus; dan kesulitan menghitung. Sehingga siswa sering mencontek punya temannya.Faktor internal yang mempengaruhi kesulitan belajar matematika siswa adalah kemampuan intelektual siswa yang rendah, sikap belajar siswa cenderung malas dan kurang disiplin, motivasi belajar rendah, konsentrasi belajar tidak bertahan lama, kemampuan mengingat beberapa siswa rendah, dan kemampuan pengindraan yang terganggu.Faktor eksternal yang mempengaruhi kesulitan belajar siswa adalah guru dalam memberikan pemahaman yang kurang jelas, lingkungan keluarga kurang mendukung, dan lingkungan sekolah yang berisik.

\section{Upaya yang dilakukan Guru Matematika dalam Mengatasi Kesulitan Belajar Siswa Madrasah Ibtidaiyah Munawariyah Palembang}

Berdasarkan hasil wawancara yang dilakukan peneliti kepada guru matematika, mengemukakan bahwa solusi dalam mengatasi kesulitan belajar siswa ada beberapa hal yang harus dilakukan: (1) Faktor guru, gaya mengajar guru harus lebih menarik, (2) Penggunaan alat bantu atau media harus jelas dan siswa langsung diajak kesituasi nyata, karena pembelajaran matematika lebih banyak realita dalam kehidupan sehari-hari. Dan (3) Pola interaksi yang bervariasi antara siswa dan guru yang akan membuat siswa dan guru lebih dekat." (Wawancara, A, Tanggal 06 September. Pukul 09.18).

Dari uraian di atas dapat disimpulkan bahwa kesulitan belajar matematika pada materi penggunaan sifat-sifat operasi hitung adalah sebagai berikut:Pertama, 14

JP: Jurnal Ilmiah PGMI, Volume 5 No. 1, Juni 2019 Available Online at http:/jurnal.radenfatah.ac.id/index.php/jip/ 
$\boldsymbol{k}$ etidakmampuan siswa dalam penguasaan konsep secara benar, seperti konsep penjumlahan dan perkalian itu siswa kelihatan bingung sehingga dapat menyebabkan ketidakmampuan siswa dalam penguasaan konsep itu kurang. Upaya yang dilakukan adalah seorang guru membuat kemampuan dasar terlebih dahulu, dimulai dengan kegiatan konsep angka dengan cara menghitung benda yang dimilikinya, sehingga anak tersebut akan paham tentang konsep angka lebih banyak, lebih sedikit, atau sama banyak. Dan adanya pengulangan disetiap akhir pembelajaran.

Kedua, ketidakmampuan siswa dalam berhitung, seperti penjumlahan, sehingga pada saat menjawab tugas yang diberikan guru ada siswa yang keliru dalam menjawab. Upaya yang harus dilakukan seorang guru memberikan kemampuan awal dari pemahaman terhadap konsep bilangan, sehingga pada pembelajaran selanjutnya anak tersebut sudah mulai menghitung dan mengingat urutan angka. Kegiatan ini dapat lebih dioptimalkan dengan menggunakan berbagai aktivitas, seperti menyanyi, permainan jari dapat dilakukan agar kemampuan menghitung anak dapat berkembang dengan cepat sesuai dengan kemampuannya.

Ketiga, ketidakmampuan siswa dalam memahami tentang simbol matematika. Upaya yang dilakukan seorang guru adalah memberikan pemahaman tentang simbol sampai anak tersebut mengerti dan paham. Anak yang mengalami kekeliruan seperti ini dapat juga karena lupa cara menghitung persoalan penjumlahan, sehingga kepada anak ini guru tidak cukup hanya diajak memahami tentang penjumlahan tetapi juga diberi latihan yang cukup. Kemudian, guru lihat hasil dari latihan tersebut jika masih ada yang belum paham, maka guru harus memberikan pemahaman lagi sampai anak mengerti dan paham.

Keempat, ketidakmampuan siswa dalam memahami perkalian. Upaya yang dilakukan guru adalah harus memberikan tes awal kepada siswa mulai dari perkalian 1-5 dengan memberikan soal di papan tulis, sampai ada siswa yang akan menjawab pertanyaan itu, dan guru juga harus lihat siapa saja yang belum bisa perkalian. Jika ada anak yang belum hafal dalam perkalian, guru harus

JIP: Jurnal Ilmiah PGMI, Volume 5 No. 1, Juni 2019

Available Online at http:/jurnal.radenfatah.ac.id/index.php/jip/ 
memberikan PR untuk menghafalkan perkalian, dan setiap pelajaran guru tersebut siswa harus menyetor perkalian tersebut. Sehingga pada saat pelajaran selanjutnya tidak ada lagi siswa yang tidak hafal. Karena pembelajaran matematika ini akan berkelanjutan dengan pembagian dan pembagian juga ada hubungannya dengan perkalian tersebut. Dan guru bisa menggunakan media matrik perkalian.

Berdasarkan teori di atas bahwa kesulitan belajar yang dialami siswa adalah Dyspraxia (Gangguan Integritas Sensory dan Dyscalculia. Dyspraxia (Gangguan Integritas Sensory adalah siswa dengan dipengaruhi oleh penurunan nilai dan sering canggung. Sehingga sulit untuk belajar dan sulit mempertahankan belajar. Sedangkan Dyscalculia adalah kesulitan belajar yang melibatkan aspek dari keterampilan aritmatika. Kesulitannya terletak pada pemahaman, penerimaan informasi kuantitatif. Kemudian, adanya dua faktor yang menyebabkan kesulitan belajar, yaitu: faktor internal dan faktor eksternal. Faktor internal adalah keadaan yang muncul dari dalam siswa, seperti pada ranah kognitif dan ranah afektif. Pada ranah kognitif terdapat bahwa ada sebagian yang mengalami intelektual rendah sehingga dapat menyebabkan dalam mengerjakan soal. Dan pada ranah afektif bahwa pada saat pembelajaran berlangsung ada yang memperhatikan, ada yang bercerita dan ada yang ribut. Faktor ekternal adalah keadaan yang muncul di luar diri siswa seperti lingkungan sekolah, di mana faktor ini yang timbul pada guru, karena pada saat pembelajaran berakhir tidak ada penggulangan terhadap materi yang telah dijelaskan.

\section{SIMPULAN}

Berdasarkan hasil penelitian dan pembahasan, maka penelitian ini dapat disimpulkan kesulitan yang dialami siswa pada pelajaran matematika materi penggunaan sifat-sifat operasi hitung di Kelas VB MI Munawariyah Palembang bahwa keulitan yang dialami siswa yaitu ketidakmampuan siswa dalam penguasaan konsep secara benar, ketidakmampuan siswa dalam berhitung, ketidakmampuan siswa dalam memahami simbol matematika, dan 
ketidakmampuan siswa dalam memahami perkalian. Sehingga kesulitan tersebut berdampak pada hasil belajar siswa.

Faktor-faktor yang menyebabkan kesulitan belajar matematika materi penggunaan sifat-sifat operasi hitung di Kelas VB MI Munawariyah Palembang meliputi faktor yang menyebabkan kesalahan dalam mengerjakan soal, faktor internal dan faktor eksternal.

Faktor yang menyebabkan siswa melakukan kesalahan dalam mengerjakan soal adalah siswa kesulitan dalam memahami maksud soal; kurang memahami konsep sifat-sifat operasi hitung; konsep memahami dan menghafal rumus; dan kesulitan menghitung. Sehingga siswa sering mencontek punya temannya.Faktor internal yang mempengaruhi kesulitan belajar matematika siswa adalah kemampuan intelektual siswa yang rendah, sikap belajar siswa cenderung malas dan kurang disiplin, motivasi belajar rendah, konsentrasi belajar tidak bertahan lama, kemampuan mengingat beberapa siswa rendah, dan kemampuan pengindraan yang terganggu.Faktor eksternal yang mempengaruhi kesulitan belajar siswa adalah guru dalam memberikan pemahaman yang kurang jelas, lingkungan keluarga kurang mendukung, dan lingkungan sekolah yang berisik.

Upaya yang dilakukan guru Matematika dalam mengatasi kesulitan belajar materi penggunaan sifat-sifat operasi hitung adalah perlunya pengajaran khusus seperti bimbingan belajar sebagai pengayaan (enrichment) dan penyembuhan (remedial) sampai pengetahuan dan keterampilan dasar serta pola-pola belajar yang sesuai terpenuhi dan dikuasai oleh siswa, perlu menggunakan media atau metode mengajar yang inovatif dan kreatif untuk mempermudah siswa, dan menciptakan conditioning (reinforcement, rewards, encouragement), serta drill. 


\section{DAFTAR PUSTAKA}

Abdurrahman, Mulyono. (2012). Anak Berkesulitan Belajar: Teori, Diagnosis, dan Remediasinya. Jakarta: PT. Rineka Cipta.

Abdurrahman, Mulyono. (2010). Pendidikan Bagi Anak Berkesulitan Belajar. Jakarta: PT. Rineka Cipta.

Amilda. (2009). Hakekat Kesulitan Belajar. Palembang:Rafah Press.

Arikunto, Suharsimi. (1993). Prosedur Penelitian Suatu Pendekatan dan Praktek. Jakarta: Rineka Cipta.

Astuti, Mardiah dan Amilda. (2012). Kesulitan Belajar Alternatif Sistem Pelayanan dan Penanganan. Yogyakarta: PT. Felicha.

Dalyono. M. (2007).Psikologi Pendidikan. Jakarta: PT. Rineka Cipta.

Hakim, Thursan. (2005). Belajar Secara Efektif. Jakarta: Puspa Swara.

Hawi, Akmal. (2006). Kompetensi Guru PAI. Palembang: IAIN Raden Fatah Press.

Ismail. (2015). Diagnosis Kesulitan Belajar Siswa dalam Pembelajaran Aktif di Sekolah.Banda Aceh: Perpustakaan UIN Ar-Raniry Banda Aceh.

Khodijah, Nyayu. (2006). Psikologi Belajar. Palembang: IAIN Raden Fatah Press.

Mulyadi. (2010).Diagnosis Kesulitan Belajar dan Bimbingan Terhadap Kesulitan Belajar Khusus. Yogyakarta: Nuha Litera.

Risnawati, Zubaidah Amir. (2016). Psikologi Pembelajaran Matematika. Yogyakarta: Penerbit Aswaja Pressindo.

Syah. Muhibbin. (1997). Psikologi Pendidikan dengan Pendekatan Baru. Bandung: PT Remaja Rosdakarya. 